\title{
ORGANIC MULCH ON EARLY GARLIC CULTIVARS GROWN UNDER SEMIARID CONDITIONS ${ }^{1}$
}

\author{
MÁRCIO AVELINO SINOIA LUÍS ${ }^{2}$, MARIA ZULEIDE DE NEGREIROS ${ }^{3}$, FRANCISCO VILELA RESENDE ${ }^{4}$, \\ RENAN DA CRUZ PAULINO ${ }^{3}$, WELDER DE ARAÚJO RANGEL LOPES ${ }^{3}$, LAÍZA GOMES DE PAIVA ${ }^{3}$
}

\begin{abstract}
Soil cover with plant residues is a traditional cultural practice in garlic crops, mainly among small producers. Virus-free garlic seeds is a recent technology used in several garlic producing regions of Brazil; it enables the maximum exploration of the productive potential of cultivars. A field experiment was developed from May to September 2018 with the objective of evaluating the use of mulching in early garlic cultivars in semiarid conditions. A randomized block experimental design was used, with a split-plot arrangement and four replications; the plots consisted of treatments with and without mulch in the plots, and the subplots consisted virus-free garlic cultivars (Araguari, Cateto Roxo, Canela de Ema, Centralina, and Gravatá) and an infected cultivar (Branco Mossoró). The soil mulch did not affect the plant height and number of leaves, but promoted increases in total and commercial yields of the cultivars, especially the Gravatá, indicating that the use of this practice is important to obtain bulbs with higher commercial value; the cultivars Branco Mossoró, Canela de Ema, and Centralina had higher number of cloves per bulb and, thus, are more indicated for the climatic conditions of the region.
\end{abstract}

Keywords: Allium sativum L. Adaptation. Mulching. Copernicia cerifera straw. Yield.

\section{COBERTURA MORTA EM CULTIVARES DE ALHO PRECOCE EM CONDIÇÕES SEMIÁRIDAS}

RESUMO - A cobertura do solo com materiais de origem vegetal é uma prática cultural tradicional na cultura do alho, especialmente entre pequenos produtores. O uso de alho-semente livre de vírus é uma tecnologia recente utilizada em várias regiões produtoras de alho do Brasil, por possibilitar a exploração do máximo potencial produtivo dos cultivares. O experimento foi desenvolvido de maio a setembro de 2018, em campo, com o objetivo de avaliar o uso da cobertura morta em cultivares de alho precoce em condições semiáridas. $\mathrm{O}$ delineamento experimental foi de blocos casualizados com quatro repetições, em parcelas subdivididas. As parcelas foram representadas pelos tratamentos com e sem cobertura morta, e as subparcelas pelos cultivares de alho livre de vírus (Araguari, Cateto Roxo, Canela de Ema, Centralina, Gravatá) e infectado Branco Mossoró. A cobertura morta do solo não influencia na altura e número de folhas, porém promove aumentos na produtividade total e comercial dos cultivares, com destaque para Gravatá, indicando que o uso dessa prática é importante na obtenção de bulbos com maior valor comercial; Os cultivares Branco Mossoró, Canela de Ema e Centralina com, maior número de bulbilhos por bulbo, são mais indicados para as condições climáticas da região.

Palavras-chave: Allium sativum L. Adaptação. Mulching. Palha de carnaubeira. Produtividade.

\footnotetext{
${ }^{*}$ Corresponding author

${ }^{1}$ Received for publication in $10 / 22 / 2019$; accepted in $02 / 19 / 2020$.

Extracted from the first author's Master's dissertation.

${ }^{2}$ Instituto de Investigação Agrícola de Moçambique, Boane district, Maputo province, Mozambique; marcio.sinoia@gmail.com - ORCID: 0000-0003-1135-0527.

${ }^{3}$ Department of Agronomic and Forestry Sciences, Universidade Federal Rural do Semi-Árido, Mossoró, RN, Brazil; zuleide@ufersa.edu.br _ ORCID: 0000-0002-0665-326X, renan@ufersa.edu.br _ ORCID: 0000-0002-1801-2363, welder.lopes@hotmail.com - ORCID: 0000-0002-9380-6710, laizagomes@outlook.com - ORCID: 0000-0002-6645-369X.

${ }^{4}$ Embrapa Hortaliças, Brasília, DF, Brazil; francisco.resende@embrapa.br - ORCID: 0000-0002-5307-4842.
} 


\section{INTRODUCTION}

Garlic (Allium sativum L.) is a vegetable of great economic and social importance in Brazil. It is mainly grown by small producers and requires much labor during its crop cycle.

The state of Rio Grande do Norte stands out as the great garlic producer in the Northeast region of Brazil, but currently it depends on garlic imports to supply its demand. The decreasing use of the regional cultivar Branco Mossoró and imports of garlics with better commercial quality from other regions of Brazil and from countries such as China, Argentina, and Spain, are among the factors responsible for the decreases and later elimination of this crop in the state (SOARES et al., 2015).

In this context, studies have been developed to bring back garlic crops to Rio Grande do Norte. They started in the Mossoró microregion, through experiments that evaluated common garlic varieties (more than 20 cloves per bulb) (HONORATO et al., 2013; SOARES et al., 2015; LUCENA et al., 2016) and noble varieties (more than 20 cloves per bulb) (LOPES et al., 2016); the latter are commercially more competitive cultivars. Considering the unfavorable climate conditions for noble garlic crops in low altitude areas, mountain regions with more appropriate climate conditions for the development of this type of garlic had most investments, focused on management and cultural practices and on adoption of virus-free garlic seeds, mainly in the Portalegre region (LIMA et al., 2019; SILVA, 2019).

Low altitude regions also had investments in virus-free garlic seed technologies, using early common cultivars because these cultivars are less demanding in photoperiod and temperature, and are more indicated for semiarid regions.

The use of virus-free garlic seeds is a great technological advance for the development of garlic crops in Brazil, since it allows the exploration of the maximum potential of the cultivars due the eradication of viruses in infected conventional materials, contributing to the obtaining of more vigorous and productive plants (RESENDE et al., 2013).

The use of soil cover became important and much used to produce several vegetable species, including garlic, by improving the quality and profitable yields of plant products. The use of soil cover with plant residues is a traditional practice for garlic crops, mainly among small producers. In extensive and mechanized areas, this practice is not economically viable because of the increase in costs, mainly labor, and acquisition and application of plant residues.

In semiarid regions, this practice is very important, since it controls soil moisture by decreasing water evaporation, making possible to increase irrigation intervals, thus contributing to water savings. Moreover, this practice reduces soil temperature, making it lower than that of the air, avoids acute thermal fluctuation in the soil, and contributes to weed control, allowing a better crop performance (FILGUEIRA, 2013).

Evaluations of virus-free garlic cultivars associated to crop managements, such as mulching, can be a viable alternative to bring back garlic crops to the Mossoró microregion. In this context, the objective of this work was to evaluate the use of mulching in early garlic cultivars in semiarid conditions.

\section{MATERIAL AND METHODS}

The experiment was conducted from May to September 2018 in the Rafael Fernandes Experimental Farm, which belongs to the Universidade Federal Rural do Semi-Árido, and is located in the rural area of the municipality of Mossoró, state of Rio Grande do Norte, Brazil $\left(5^{\circ} 03^{\prime} 37^{\prime \prime} \mathrm{S}, 37^{\circ} 23^{\prime} 53^{\prime \prime} \mathrm{W}\right.$, and altitude of $\left.80 \mathrm{~m}\right)$. The climate of the region is BSh, according to the Köppen classification (ALVARES et al., 2013).

The microclimate effects of each soil cover were monitored using devices of data collection installed at a height of $1.50 \mathrm{~m}$ from the soil surface in the evaluation area of two subplots, with two replications, throughout the crop cycle. The copperbased sensors were placed at $0.10 \mathrm{~m}$ depth into the soil, connected to automatic devices of data collection, and programmed for solar radiation, air relative humidity, and air and soil temperature readings, with and without mulch (Figure 1).

The soil of the experimental area was classified as eutrophic Typic Hapludult (Argissolo Vermelho-Amarelo Eutrófico) of sandy loam texture and plain relief (RÊGO et al., 2016). The soil chemical analysis presented the following characteristics: $\mathrm{pH}$ of 6.00 , electrical conductivity of $0.07 \mathrm{dSm}^{-1}, 6.03 \mathrm{~g} \mathrm{~kg}^{-1}$ of organic matter, $0.42 \mathrm{~g} \mathrm{~kg}^{-1}$ of $\mathrm{N}, 4.8 \mathrm{mg} \mathrm{dm}^{-3}$ of $\mathrm{P}, 26.1 \mathrm{mg} \mathrm{dm}^{-3}$ of $\mathrm{K}^{+}, 1.55$ $\mathrm{cmol}_{\mathrm{c}} \mathrm{dm}^{-3}$ of $\mathrm{Ca}^{2+}, 1.15 \mathrm{cmol}_{\mathrm{c}} \mathrm{dm}^{-3}$ of $\mathrm{Mg}^{2+}, 0.00$ $\mathrm{cmol}_{\mathrm{c}} \mathrm{dm}^{-3}$ of $\mathrm{Al}^{3+}, 0.83 \mathrm{cmol}_{\mathrm{c}} \mathrm{dm}^{-3}$ of $\mathrm{H}+\mathrm{Al}, 2.79$ $\mathrm{cmol}_{\mathrm{c}} \mathrm{dm}^{-3}$ of sum of bases, $3.62 \mathrm{cmol}_{\mathrm{c}} \mathrm{dm}^{-3}$ of cation exchange capacity (CEC), $2.79 \mathrm{cmol}_{\mathrm{c}} \mathrm{dm}^{-3}$ of effective CEC, $77 \%$ base saturation, $0.0 \%$ aluminum saturation, and $1 \%$ exchangeable sodium. 

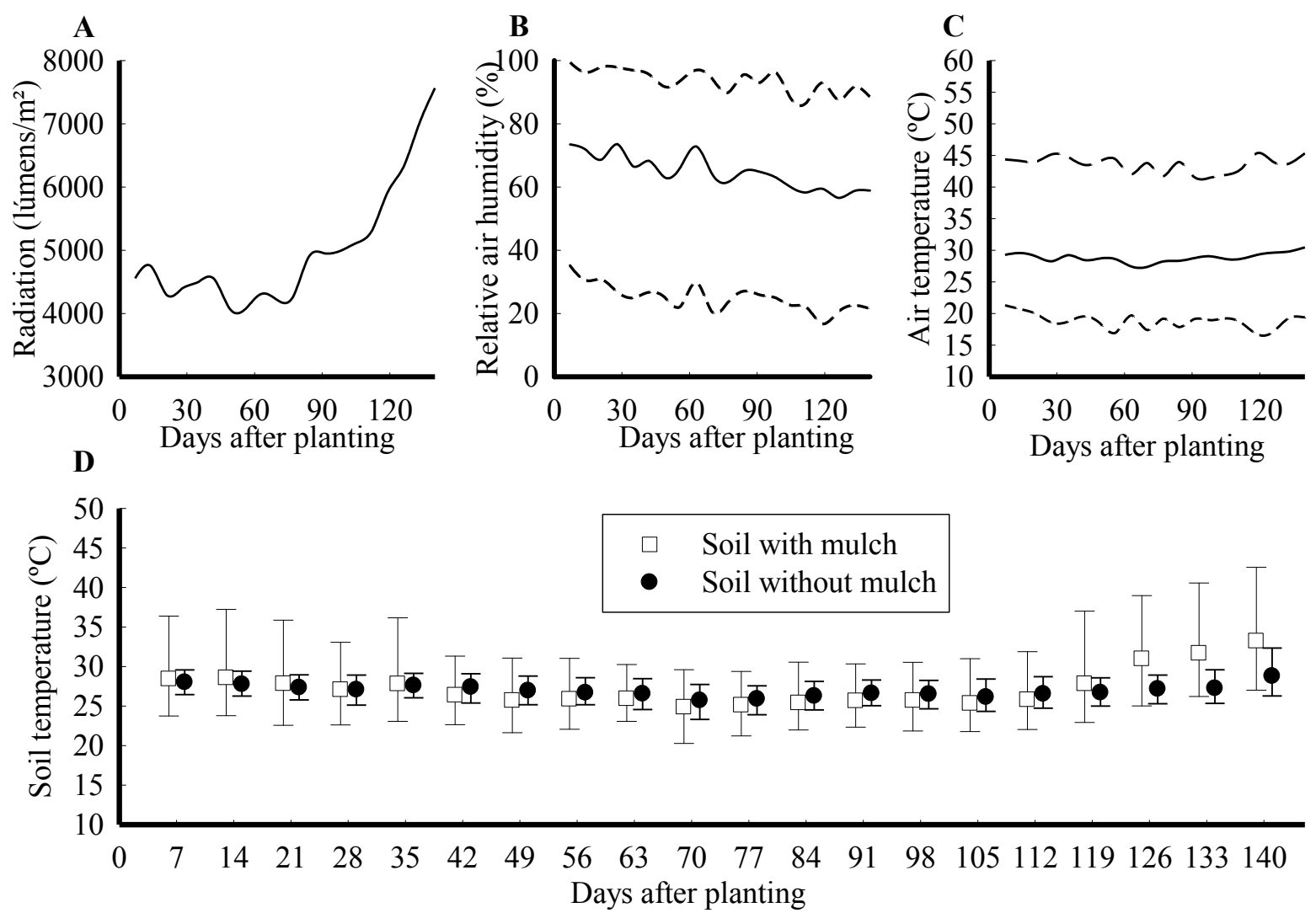

Figure 1. Solar radiation (A); relative air humidity (B); air temperature (C); and soil temperature (D), with and without mulch, in the experimental area during the experiment.

The soil preparation consisted of plowing and harrowing, followed by raising of beds, when the planting soil fertilization was done based on the soil chemical analysis and recommendations of Holanda et al. (2017) and Resende, Dusi and Melo (2004) for garlic crops. The nutrients $\mathrm{N}, \mathrm{P}, \mathrm{K}, \mathrm{Mg}, \mathrm{B}$, and $\mathrm{Zn}$ were applied using ammonium sulfate $\left(150 \mathrm{~kg} \mathrm{ha}^{-1}\right)$, simple superphosphate $\left(1000 \mathrm{~kg} \mathrm{ha}^{-1}\right)$, potassium chloride (52 $\left.\mathrm{kg} \mathrm{ha}{ }^{-1}\right)$, magnesium sulfate $\left(150 \mathrm{~kg} \mathrm{ha}^{-1}\right)$, boric acid $\left(9.68 \mathrm{~kg} \mathrm{ha}^{-1}\right)$, and zinc sulfate $\left(60 \mathrm{~kg} \mathrm{ha}^{-1}\right)$, respectively. The fertilizers were incorporated into the beds at ten days before planting. $\mathrm{N}$ and $\mathrm{K}$ topdressing were applied in two applications, at 30 and 60 days after planting (DAP), using calcium nitrate (120 and $\left.140 \mathrm{~kg} \mathrm{ha}^{-1}\right)$ and potassium nitrate $\left(90.91\right.$ and $\left.68.18 \mathrm{~kg} \mathrm{ha}^{-1}\right)$, respectively.

The experiment was conducted in a randomized block design, with split-plot arrangement and four replications; the plots consisted of treatments with and without mulch in the plots, and the subplots consisted virus-free garlic cultivars (Araguari, Cateto Roxo, Canela de Ema, Centralina, and Gravatá) and an infected cultivar (Branco Mossoró). The plots were represented by mulch with straw of crushed carnauba (Copernicia cerifera Mart.) and without mulch (control); and the subplots consisted of six garlic cultivars: Araguari, Branco Mossoró, Canela de Ema, Centralina, Cateto
Roxo and Gravatá. The virus-free garlic cultivars were from the Embrapa Vegetables (Brasília, DF, Brazil), except the Branco Mossoró.

The preparation of the garlic seeds consisted of threshing of bulbs and classification of cloves by size; they were planted in blocks, according to their class for a higher uniformity of the stand. The cloves were treated with $2.5 \%$ iprodione solution $\left(1.5 \mathrm{ml} \mathrm{L}^{-1}\right)$ before planting to prevent attacks of soil pathogens.

A layer of $0.03 \mathrm{~m}$ of the crushed carnauba straw was applied to the soil surface of each subplot after the planting and before the emergence of plants.

The subplots consisted of beds of $0.20 \mathrm{~m}$ height, $1.20 \mathrm{~m}$ width, and $1.50 \mathrm{~m}$ length, with five planting rows. The seeds were planted in simple rows to a depth of $0.05 \mathrm{~m}$, with spacing of $0.20 \mathrm{~m}$ between rows and $0.10 \mathrm{~m}$ between plants, resulting in a population of 75 plants in the total area $\left(1.8 \mathrm{~m}^{2}\right)$.

A micro sprinkler system was used for irrigation, with pressure of $200 \mathrm{KPa}$ for a flow of 40 $\mathrm{L} \mathrm{h}^{-1}$, with two micro sprinkler per subplot; the water irrigation depths were applied according to the need of the crop.

Weeds were controlled manually in the subplots with and without mulch when needed; the fields were kept free of weeds during the whole cycle.

Phytosanitary control consisted of application 
of products based on mancozeb (Manzate ${ }^{\odot} \mathrm{WG}$ ) and pyraclostrobin (Cabrio ${ }^{\circledR}$ Top) with 7 to 10-day intervals after 30 days after planting (DAP) to prevent and control purple seed stain. Pests, such as thrips and mites, were controlled by applying products based on chlorfenapyr $\left(\right.$ Pirate $\left.^{\mathbb{R}}\right)$ and deltamethrin (Decis 25 EC) after 30 DAP, with 15day intervals.

The irrigation was suspended at five days before harvest, when the plants presented signals of maturation, which were characterized by shoot yellowing and partial drying. The plants harvested were subjected to a pre-cure process, remaining exposed to the Sun for 3 to 5 days, with the leaves of plants covering the bulbs of the other ones to protect them from direct solar radiation. Subsequently, they were subjected to a shade cure, remaining in a dry, fresh place for 20 days. After the cure process, they were cleaned the roots, dry and dirt leaves and layers were removed from the bulbs. Then, the following characteristics were evaluated:

Emergence of plants (\%): obtained by counting the number of plants emerged at 35 DAP;

Number of leaves: obtained by counting the photosynthetically active leaves of ten plants of the evaluation area of the subplot at 70 DAP;

Plant height $(\mathrm{cm})$ : determined by measuring the distance from the ground to the extremity of the longest leaf in ten plants of the evaluation area of the subplot at 70 DAP;

Crop cycle (days): determined by the number of days from planting to harvest;

Bulb mean weight $(\mathrm{g})$ : obtained through the ratio between bulb weight and total number of bulbs;

Total bulb yield $\left(\mathrm{Mg} \mathrm{ha}{ }^{-1}\right)$ : determined by weighing the bulbs of each subplot after the cure process;

Bulb class: obtained according to the bulb transversal diameter (Ordinance no. 242 of 17/09/1992 of the Brazilian Ministry of Agriculture, Livestock, and Supply) as class 3 (higher than 32 up to $37 \mathrm{~mm}$ ), class 4 (higher than 37 up to $42 \mathrm{~mm}$ ), class 5 (higher than 42 up to $47 \mathrm{~mm}$ ), class 6 (higher than 47 up to $56 \mathrm{~mm}$ ), and class 7 (higher than $56 \mathrm{~mm}$ ). The bulbs of each class were weighed and the data were expressed in percentage of each class in relation to the total bulb production;

Commercial yield $\left(\mathrm{Mg} \mathrm{ha}^{-1}\right)$ : obtained by total weight of bulbs with transversal diameter above 32 $\mathrm{mm}$ (classes 3 to 7);

Number of cloves per bulb (unity): determined by the relation between number of cloves and total number of bulbs;

Clove class: the cloves were defined as large when retained in sieve $1(15 \times 25 \mathrm{~mm}$ mesh $)$; average, when retained in sieve $2(10 \times 20 \mathrm{~mm}$ mesh); average-small, when retained in sieve $3(8 \times$ $17 \mathrm{~mm}$ mesh); small, when retained in sieve $4(5 \times$ $17 \mathrm{~mm} \mathrm{mesh}$ ); and sticks, when passing through sieve 4 .
The data were subjected to analysis of variance, using-se the program SISVAR v.5.7. The means of the cultivars were compared by the ScottKnott test at 5\% probability, and the effect of the soil much was compared through the t Student test at 5\% probability (FERREIRA, 2011).

\section{RESULTS AND DISCUSSION}

The interaction between mulch and cultivars was significant for emergence of plants (EP), number of leaves (NL), crop cycle (CC), total yield (TY), commercial yield (CY), mean bulb weight (MBW), and number of cloves per bulb (NCB). The cultivars had significant isolate effect for plant height.

The percentage of emergence in the treatment without soil cover was significantly higher than that in the treatment with soil cover. The comparison of cultivars in each soil cover showed that the mean percentage of emergence of the cultivars Canela de Ema, Cateto Roxo, and Araguari (94.78\%) were higher than that of the cultivars Branco Mossoró, Centralina, and Gravatá $(89.78 \%)$, in the presence of soil cover. Contrastingly, no significant difference was found between cultivars in the treatment without soil cover, which presented a mean emergence of 98.12\% (Table 1).

The NL of the plants showed that the soil cover did not affect significantly this variable. However, significant differences between cultivars were found for each soil cover. The highest NL in the treatment with mulch was found for the cultivars Branco Mossoró (8.55) and Canela de Ema (8.40). The highest NL in the treatment without mulch were found for Branco Mossoró (8.50) and Centralina (8.60), and the lowest for the Araguari, which had 6.53 leaves in both treatments (Table 1). The soil cover had no effect on NL probably due to the adaptation of the cultivars to the local climatic conditions, although the crop management could have affected the results (HENRIQUES et al., 2019).

The NL of the cultivars Branco Mossoró (8.53), Gravatá (7.71), and Cateto Roxo (7.89) were also evaluated in other studies in the region. Soares et al. (2015) found mean NL of 9.40, and Honorato et al. (2013) found mean NL of 7.75 for the cultivar Branco Mossoró. Soares et al. (2015) found mean NL of 9.60 and 9.10, and Honorato et al. (2013) found mean NL of 7.50 and 5.25 for the cultivars Gravatá and Cateto Roxo, respectively. The results found denote that garlic cultivars may present morphological differences due to environmental conditions. Positive effect of mulch on garlic NL was found by Seifu et al. (2017), with better results for black polyethylene (15.36 leaves) and grass (14.06 leaves), when compared to the soil without cover (9.9 leaves). 
Table 1. Means for emergence of plants, number of leaves, and crop cycle of virus-free early garlic cultivars grown with and without soil cover.

\begin{tabular}{|c|c|c|c|c|c|c|}
\hline \multirow[t]{2}{*}{ Cultivar } & \multicolumn{2}{|c|}{$\begin{array}{c}\text { Emergence } \\
(\%)\end{array}$} & \multicolumn{2}{|c|}{$\begin{array}{c}\text { Number of leaves } \\
\text { (leaves plant }^{-1} \text { ) }\end{array}$} & \multicolumn{2}{|c|}{$\begin{array}{c}\text { Crop cycle } \\
\text { (days) }\end{array}$} \\
\hline & With soil cover & $\begin{array}{c}\text { Without soil } \\
\text { cover }\end{array}$ & With soil cover & $\begin{array}{c}\text { Without soil } \\
\text { cover }\end{array}$ & With soil cover & $\begin{array}{c}\text { Without soil } \\
\text { cover }\end{array}$ \\
\hline B.Mossoró & $91.33 \mathrm{~b} \mathrm{~B}$ & 95.67 a A & $8.55 \mathrm{a} \mathrm{A}$ & $8.50 \mathrm{a} \mathrm{A}$ & $125.35 \mathrm{~b} \mathrm{~A}$ & $119.35 \mathrm{~b} \mathrm{~B}$ \\
\hline C. de Ema & 94.33 a B & 98.67 a A & $8.40 \mathrm{a} A$ & $7.83 \mathrm{~b} \mathrm{~A}$ & $125.45 \mathrm{~b} \mathrm{~A}$ & $119.25 \mathrm{~b} \mathrm{~B}$ \\
\hline C. Roxo & 94.66 a B & 99.67 a A & $7.78 \mathrm{~b} \mathrm{~A}$ & $8.00 \mathrm{~b} \mathrm{~A}$ & $125.35 \mathrm{~b} \mathrm{~A}$ & 119.22 b B \\
\hline Centralina & $90.00 \mathrm{~b} \mathrm{~B}$ & 99.67 a A & $8.05 \mathrm{~b} \mathrm{~A}$ & $8.60 \mathrm{a} \mathrm{A}$ & $119.25 \mathrm{c} \mathrm{A}$ & $117.77 \mathrm{~b} \mathrm{~A}$ \\
\hline Gravatá & $88.00 \mathrm{~b} \mathrm{~B}$ & 96.34 a A & $8.13 \mathrm{~b} \mathrm{~A}$ & $7.28 \mathrm{c} \mathrm{A}$ & $125.47 \mathrm{~b} \mathrm{~A}$ & 119.32 b B \\
\hline Araguari & 95.34 a B & 98.67 a A & $6.53 \mathrm{c} \mathrm{A}$ & $6.53 \mathrm{~d} \mathrm{~A}$ & 145.35 a A & 145.35 a A \\
\hline $\mathrm{CV}_{\text {Cover }}(\%)$ & \multicolumn{2}{|c|}{5.80} & \multicolumn{2}{|c|}{23.34} & \multicolumn{2}{|c|}{1.86} \\
\hline $\mathrm{CV}_{\text {Cultivar }}(\%)$ & \multicolumn{2}{|c|}{6.89} & \multicolumn{2}{|c|}{4.50} & \multicolumn{2}{|c|}{1.17} \\
\hline
\end{tabular}

Means followed by uppercase letters in the rows compare soil cover within each cultivar using the $t$ Student test (LSD) at $5 \%$ probability; lowercase letters in the columns compare cultivar within each soil cover using the Scott-Knott test at 5\% probability.

Plant height was not affected by soil cover, but it was significantly affected by the cultivars. The higher heights were found for the cultivars Branco
Mossoró, Centralina, and Gravatá, which reached a mean of $47.67 \mathrm{~cm}$, whereas Canela de Ema, Cateto Roxo, and Araguari reached a mean of $42.39 \mathrm{~cm}$ (Table 2).

Table 2. Means for plant height of early garlic cultivars grown with and without soil cover.

\begin{tabular}{lc}
\hline Soil cover & Plant height (cm) \\
\hline With cover & $42.87 \mathrm{a}^{*}$ \\
Without cover & $47.20 \mathrm{a}$ \\
\hline Cultivar & $47.79 \mathrm{a} * *$ \\
\hline Branco Mossoró & $42.68 \mathrm{~b}$ \\
Canela de Ema & $44.28 \mathrm{~b}$ \\
Cateto Roxo & $47.29 \mathrm{a}$ \\
Centralina & $47.94 \mathrm{a}$ \\
Gravatá & $40.23 \mathrm{~b}$ \\
Araguari & 17.24 \\
\hline CV $_{\text {Cover }}(\%)$ & 6.99 \\
CV $_{\text {Cultivar }}(\%)$ & \\
\hline
\end{tabular}

*Means followed by same letter are not different by the t Student test (LSD) at $5 \%$ probability. **Means followed by same letter are not different by the Scott-Knott test at 5\% probability. 
The soil cover had significant effect on the crop cycle; the cultivars presented shorter cycles in the treatment without soil cover (Table 1).

Considering the cultivars in each soil cover treatment, in the presence of mulch, the cultivar Centralina presented shorter cycle (119.25 days) than the Branco Mossoró, Canela de Ema, Cateto Roxo, and Gravatá, which presented mean crop cycle of 125.41 days. The cultivar Araguari had the longest cycle, with 145.35 days from planting to harvest. The cultivar Araguari also had the longest cycle in the treatment without soil cover, with 145.35 days, whereas the other cultivars reached a mean cycle of 118.98 days (Table 1 ).

The cultivars Branco Mossoró, Canela de Ema, Cateto Roxo, and Gravatá were probably less demanding in terms of climate (photoperiod and temperature), and had better results in the environment with soil cover (Figure 1D). Thus, under mild soil temperature conditions, the cultivars presented a slower growth, resulting in a significantly longer cycle than that of the cultivar Centralina. This cultivar is probably more demanding and did not benefit from the mulch, presenting a faster growth and, consequently, a shorter cycle. This was not found in the treatment without soil cover; only the cultivar Araguari, which is more demanding in terms of climate, had longer cycle, regardless of the presence of soil cover.

The soil cover had significant effect on total yield (TY) and commercial yield (CY) within each cultivar. The cultivar Gravatá had significantly higher TY and CY in the treatment with soil cover (Table 3). This cultivar had 55\% higher TY and 78\% higher $\mathrm{CY}$ in the treatment with soil cover.

Table 3. Means for total and commercial yields of virus-free early garlic cultivars grown with and without soil cover.

\begin{tabular}{|c|c|c|c|c|}
\hline \multirow[t]{3}{*}{ Cultivar } & \multicolumn{2}{|c|}{ Total yield $\left(\mathrm{Mg} \mathrm{ha}^{-1}\right)$} & \multicolumn{2}{|c|}{ Commercial yield $\left(\mathrm{Mg} \mathrm{ha}^{-1}\right)$} \\
\hline & With & Without & With & Without \\
\hline & soil cover & soil cover & soil cover & soil cover \\
\hline Branco Mossoró & $4.75 \mathrm{c} \mathrm{A}$ & $5.11 \mathrm{a} \mathrm{A}$ & $4.18 \mathrm{c} \mathrm{A}$ & 4.79 a A \\
\hline Canela de Ema & $6.44 \mathrm{~b} \mathrm{~A}$ & $5.25 \mathrm{a} \mathrm{A}$ & $6.09 \mathrm{~b} \mathrm{~A}$ & $4.80 \mathrm{a} \mathrm{A}$ \\
\hline Cateto Roxo & $6.31 \mathrm{~b} \mathrm{~A}$ & 5.58 a A & $6.17 \mathrm{~b} \mathrm{~A}$ & 5.19 a A \\
\hline Centralina & $5.51 \mathrm{c} \mathrm{A}$ & $6.10 \mathrm{a} A$ & $4.91 \mathrm{c} \mathrm{A}$ & $6.08 \mathrm{a} \mathrm{A}$ \\
\hline Gravatá & 7.99 a A & 5.17 a B & 7.90 a $\mathrm{A}$ & 4.45 a B \\
\hline Araguari & $3.41 \mathrm{~d} \mathrm{~A}$ & $3.10 \mathrm{~b} \mathrm{~A}$ & $0.53 \mathrm{~d} \mathrm{~A}$ & $0.94 \mathrm{~b} \mathrm{~A}$ \\
\hline $\mathrm{CV}_{\text {Cover }}(\%)$ & \multicolumn{2}{|c|}{18.80} & \multicolumn{2}{|c|}{19.74} \\
\hline $\mathrm{CV}_{\text {Cultivar }}(\%)$ & \multicolumn{2}{|c|}{14.68} & \multicolumn{2}{|c|}{19.86} \\
\hline
\end{tabular}

Means followed by uppercase letters in the rows compare soil cover within each cultivar using the $t$ Student test (LSD) at $5 \%$ probability; lowercase letters in the columns compare cultivar within each soil cover using the Scott-Knott test at 5\% probability.

Considering the cultivars within each soil cover, in the presence of mulch, the cultivar Gravatá had higher TY and CY (7.99 and 7.90 $\left.\mathrm{Mg} \mathrm{ha}^{-1}\right)$, followed by the cultivars Canela de Ema (6.44 and 6.09 $\mathrm{Mg} \mathrm{ha}^{-1}$ ), Cateto Roxo (6.31 and 6.17 $\left.\mathrm{Mg} \mathrm{ha}^{-1}\right)$, Centralina (5.51 and 4.91 $\mathrm{Mg} \mathrm{ha}^{-1}$ ), Branco Mossoró (4.75 and $4.18 \mathrm{Mg} \mathrm{ha}^{-1}$ ), and Araguari (3.41 and $\left.0.53 \mathrm{Mg} \mathrm{ha}^{-1}\right)$. In the absence of mulch, no significant difference in $\mathrm{TY}$ and $\mathrm{CY}$ was found between cultivars, except for Araguari (Table 3).

In the treatment without soil cover, the TY of the cultivars Branco Mossoró (5.11 $\mathrm{Mg} \mathrm{ha}^{-1}$ ), Cateto
Roxo (5.58 $\left.\mathrm{Mg} \mathrm{ha}^{-1}\right)$, and Gravatá (5.17 $\mathrm{Mg} \mathrm{ha}^{-1}$ ) were above those found in other studies (HONORATO et al., 2013; SOARES et al., 2015). Honorato et al. (2013) found 2.39, 1.83, and $1.86 \mathrm{Mg}$ $\mathrm{ha}^{-1}$, and Soares et al. (2015) found 5.50, 4.25, and $4.50 \mathrm{Mg} \mathrm{ha}^{-1}$ for the cultivars Branco Mossoró, Cateto Roxo, and Gravatá, respectively. The higher TY of the cultivars Cateto Roxo and Gravatá can be due to their phytosanitary quality, since they were from virus-free garlic clones.

Increases in garlic yield due to the use of mulch are found in other studies (KUMAR; LAL, 
2012; KABIR et al., 2013; MORAVČEVIĆ et al. 2014; FIRISSA; SEYOUM; ABEGAZ, 2019). This can be explained by the benefits of mulch to soil moisture and temperature control, avoiding acute thermal fluctuations (KUMAR; LAL, 2012) and contributing to partial or total removal of weeds (FILGUEIRA, 2013), which results in a better agronomic and economic performance of the crop.

However, increases in crop yield due to the use of mulch vary as a function of type, thickness, application mode of the mulch used as soil cover, and the garlic clone used due to the edaphoclimatic conditions required for them in the crop environment.

Considering the soil cover within each cultivar, the cultivars Canela de Ema and Gravatá had significantly higher MBW in the treatment with soil cover, whereas the other cultivars had no significant difference in MWB between the treatments (Table 4).

Table 4. Mean weight of bulbs (MBW) and bulb class of virus-free early garlic cultivars grown with and without soil cover.

\begin{tabular}{|c|c|c|c|c|c|c|}
\hline \multirow{3}{*}{ Cultivar } & \multicolumn{6}{|c|}{ Classification $(\%)^{*}$} \\
\hline & $\mathrm{MBW} * *$ & Non-commercial & Class 3 & Class 4 & Class 5 & Class 6 \\
\hline & \multicolumn{6}{|l|}{$\left(\right.$ g bulb $\left.^{-1}\right)$} \\
\hline & \multicolumn{6}{|c|}{ With soil cover } \\
\hline Branco Mossoró & $12.90 \mathrm{c} \mathrm{A}$ & 12.5 & 49.26 & 36.54 & 2.05 & 0.00 \\
\hline Canela de Ema & $17.75 \mathrm{~b} \mathrm{~A}$ & 6.10 & 19.37 & 32.04 & 40.41 & 1.58 \\
\hline Cateto Roxo & $16.82 \mathrm{~b} \mathrm{~A}$ & 2.51 & 21.87 & 40.92 & 34.70 & 0.00 \\
\hline Centralina & $14.68 \mathrm{c} \mathrm{A}$ & 11.09 & 42.83 & 35.77 & 10.30 & 0.00 \\
\hline Gravatá & 21.73 a A & 1.24 & 14.85 & 33.55 & 48.58 & 1.78 \\
\hline Araguari & $9.47 \mathrm{~d} \mathrm{~A}$ & 84.68 & 15.32 & 0.00 & 0.00 & 0.00 \\
\hline \multirow[t]{2}{*}{ Means } & & 19.69 & 27.25 & 29.80 & 22.67 & 0.56 \\
\hline & \multicolumn{6}{|c|}{ Without soil cover } \\
\hline Branco Mossoró & $14.36 \mathrm{a} \mathrm{A}$ & 6.71 & 57.39 & 32.78 & 3.13 & 0.00 \\
\hline Canela de Ema & 14.29 a B & 8.28 & 39.11 & 43.51 & 9.10 & 0.00 \\
\hline Cateto Roxo & 15.67 a A & 7.39 & 39.65 & 39.61 & 13.35 & 0.00 \\
\hline Centralina & 16.27 a A & 0.57 & 49.55 & 39.05 & 10.82 & 0.00 \\
\hline Gravatá & 13.87 a B & 14.60 & 52.87 & 28.99 & 3.54 & 0.00 \\
\hline Araguari & $8.71 \mathrm{~b} \mathrm{~A}$ & 77.15 & 22.85 & 0.00 & 0.00 & 0.00 \\
\hline Means & & 19.12 & 43.57 & 30.66 & 6.66 & 0.00 \\
\hline $\mathrm{CV}_{\text {Cover }}(\%)$ & 16.48 & & & & & \\
\hline $\mathrm{CV}_{\text {Cultivar }}(\%)$ & 14.65 & & & & & \\
\hline
\end{tabular}

*Classes: non-commercial (<32 mm), 3 (>32 up to $37 \mathrm{~mm}$ ), 4 (>37 up to $42 \mathrm{~mm}$ ), 5 (>42 up to $47 \mathrm{~mm}$ ), and 6 ( $>47$ up to $52 \mathrm{~mm}$ ). Data expressed in percentage of each class in relation to the total production. **Means followed by uppercase letters in the rows compare soil cover within each cultivar using the t Student test (LSD) at 5\% probability; lowercase letters in the columns compare cultivar within each soil cover using the Scott-Knott test at $5 \%$ probability. 
Considering the cultivars in the treatment with soil cover, the MBW varied from 21.73 to $9.47 \mathrm{~g}$. The cultivar Gravatá had the highest MBW, and Araguari had the lowest. The cultivars Canela de Ema and Cateto Roxo had similar MBW, with mean of $17.29 \mathrm{~g}$, whereas Branco Mossoró and Centralina had MBW of $13.79 \mathrm{~g}$. In the treatment without mulch, the MBW varied from 16.27 to $8.71 \mathrm{~g}$; the cultivar Araguari had the lowest MBW. The other cultivars had similar MBW, with mean of $14.89 \mathrm{~g}$ (Table 4). The MBW found for the cultivars Branco Mossoró, Cateto Roxo, and Gravatá in the treatment without soil cover were similar to those found by Soares et al. (2015) for these cultivars, $16.75 \mathrm{~g}$, $11.75 \mathrm{~g}$, and $14.00 \mathrm{~g}$, respectively.

Regarding the bulb classes (Table 4) relative to the total bulb yield (Table 3), the commercial yield of the cultivars in the treatment with mulch was distributed in the classes 3, 4, 5, and 6, except for Araguari. The cultivars Canela de Ema, Gravatá, and Cateto Roxo had the highest percentage of bulbs of classes 4 and 5; Gravatá, and Cateto Roxo had small percentages of bulbs of class 6 , class of higher commercial value. The commercial yields of the cultivars Branco Mossoró and Centralina were concentrated in the classes 3 and 4, and the cultivar Araguari had only class 3 bulbs, with predominance of more than $80 \%$ non-commercial bulbs (Table 4 ). The highest concentration of commercial yield of the cultivars Branco Mossoró and Araguari in the classes 3 and 4 was because the first is not a virus-free garlic clone, and the second is not adapted to the local climatic conditions

Regarding the crop without mulch, the commercial yield was distributed in the classes 3 and 5 ; the highest commercial bulb production was concentrated in the classes 3 and 4 (Table 4), except for the cultivar Araguari, which presented 77.15\% non-commercial bulbs. These results are partly similar to those of Soares et al. (2015), who found commercial yield of the cultivar Branco Mossoró distributed in the classes 3 and 5, although with higher percentage in the classes 3 and 4; and commercial yield of the cultivar Cateto Roxo and Gravatá distributed in the classes 3 and 4, but with higher concentration in the class 3 . Contrastingly, Honorato et al. (2013) evaluated these same cultivars and found lower total yield than those found in the present work; and Soares et al. (2015) found higher percentage of non-commercial bulbs (diameter lower than $32 \mathrm{~mm}$ ), and class 3 bulbs.

The total yield of the treatments showed that the use of soil cover resulted in higher percentage of bulbs of classes 4,5 , and 6 , and lower percentage of bulbs of class 3 when compared to soil without cover. Thus, the cultivars that presented higher productive performance had higher percentage of commercial bulbs of classes 4,5 , and 6 , and lower of class 3 , indicating a direct relation between garlic bulb classes (diameter) and commercial yield (Table 3).

The soil cover had significant effect on number of cloves per bulb (NCB) for the cultivar Gravatá, which presented higher NCB in the treatment with mulch, and for Canela de Ema and Centralina, in the treatment without mulch. The other cultivars had no significant differences in NCB due to the soil cover (Table 5). Moravčević et al. (2014) report that the $\mathrm{NCB}$ is an intrinsic genetic characteristic of garlic cultivars, and rarely is affected by biotic and/or abiotic factors, such as soil cover.

Considering the cultivars within each soil cover, the NCB varied from 13.47 to 2.48 in the presence of mulch; the cultivars Centralina (13.47), Branco Mossoró (10.58), and Canela de Ema (6.48) had higher NCB than the Gravatá (5.90), Cateto Roxo (4.38), and Araguari (2.48). The cultivars Centralina (15.68), Branco Mossoró (10.53), and Canela de Ema (8.95) had higher NCB than the other cultivars in the treatment without mulch (Table 5).

Considering the classification of cloves, the cultivars Branco Mossoró, Centralina ,and Canela de Ema presented the highest $\mathrm{NCB}$ in the treatment with mulch, with more than $90 \%$ of the cloves retained in sieves 2, 3, and 4 . The cultivars Cateto Roxo (4.38 NCB) and Gravatá (5.90 NCB) had higher percentage of large cloves, i.e., those retained in the sieves 1 and 2 (Table 5).

The classification of cloves of the cultivars Branco Mossoró and Canela de Ema in the treatment without soil cover was similar; they had the highest percentage of cloves retained in the sieves 2,3 , and 4. The cultivars Cateto Roxo and Gravatá also presented high percentage of large cloves, which have higher commercial value (Table 5). 
M. A. S. LUÍS et al.

Table 5. Number of cloves per bulb (NCB) and classes of cloves of virus-free early garlic cultivars grown with and without soil cover.

\begin{tabular}{|c|c|c|c|c|c|c|}
\hline \multirow[b]{2}{*}{ Cultivar } & \multirow[b]{2}{*}{$\mathrm{NCB} * *$} & \multicolumn{4}{|c|}{ Classification (\%)* } & \multirow[b]{2}{*}{ Stick } \\
\hline & & Sieve 1 & Sieve 2 & Sieve 3 & Sieve 4 & \\
\hline & \multicolumn{6}{|c|}{ With soil cover } \\
\hline Branco Mossoró & $10.58 \mathrm{~b} \mathrm{~A}$ & 0.97 & 17.46 & 43.99 & 35.79 & 1.80 \\
\hline Canela de Ema & $6.48 \mathrm{c} \mathrm{B}$ & 3.28 & 52.42 & 32.51 & 10.53 & 1.27 \\
\hline Cateto Roxo & $4.38 \mathrm{~d} \mathrm{~A}$ & 19.78 & 60.03 & 18.59 & 1.60 & 0.00 \\
\hline Centralina & 13.47 a B & 2.5 & 23.56 & 30.16 & 39.17 & 4.61 \\
\hline Gravatá & $5.90 \mathrm{c} \mathrm{A}$ & 25.86 & 40.74 & 11.73 & 21.67 & 0.00 \\
\hline Araguari & 2.48 e A & 0.86 & 18.60 & 62.38 & 17.29 & 0.86 \\
\hline \multirow[t]{2}{*}{ Means } & & 8.87 & 35.47 & 33.23 & 21.01 & 1.42 \\
\hline & \multicolumn{6}{|c|}{ Without soil cover } \\
\hline Branco Mossoró & $10.53 \mathrm{~b} \mathrm{~A}$ & 0.00 & 17.04 & 48.85 & 32.62 & 0.00 \\
\hline Canela de Ema & $8.95 \mathrm{~b} \mathrm{~A}$ & 1.72 & 27.54 & 47.44 & 23.30 & 0.00 \\
\hline Cateto Roxo & $4.53 \mathrm{c} \mathrm{A}$ & 19.03 & 54.47 & 22.62 & 3.88 & 0.00 \\
\hline Centralina & 15.68 a A & 0.00 & 2.72 & 37.12 & 54.69 & 5.47 \\
\hline Gravatá & 4.10 c B & 16.95 & 51.27 & 28.70 & 3.07 & 0.00 \\
\hline Araguari & $2.43 \mathrm{~d} \mathrm{~A}$ & 7.80 & 44.29 & 35.62 & 12.29 & 0.00 \\
\hline Means & & 7.58 & 32.88 & 36.72 & 21.64 & 0.91 \\
\hline $\mathrm{CV}_{\text {Cover }}(\%)$ & 2.35 & & & & & \\
\hline $\mathrm{CV}_{\text {Cultivar }}(\%)$ & 15.59 & & & & & \\
\hline
\end{tabular}

*Percentage of number of cloves in each sieve $(1,2,3,4$, and stick) in relation to the total number of cloves. **Means followed by uppercase letters in the rows compare soil cover within each cultivar using the $t$ Student test (LSD) at $5 \%$ probability; lowercase letters in the columns compare cultivar within each soil cover using the Scott-Knott test at $5 \%$ probability.

Considering the NCB, the results indicate a higher adaptability for the cultivars Centralina, Branco Mossoró, and Canela de Ema to the edaphoclimatic conditions of the region. Virus-free garlic cultivars were initially multiplied in controlled environment with screens in Brasília, DF, Brazil, and they were planted for the first time in field conditions in Mossoró, RN, Brazil, where they had no adequate bulbing, resulting in low number of cloves per bulb. It is believed that in the second year of the crop, these cultivars will be more adapted to the climatic conditions of the region and will present a better agronomical performance.

\section{CONCLUSIONS}

The soil mulch had no effect on plant height and number of leaves of the garlic cultivars evaluated; however, it affected the emergence of cultivars that have more efficient germination in soils without cover;

The use of mulch promotes significant increases in the mean bulb weight and total and commercial yields of the cultivar Gravatá;

The cultivars Branco Mossoró, Canela de Ema, and Centralina had higher number of cloves per bulb, denoting a higher adaptability to the 
climatic conditions of the region;

Soil mulch results in a higher percentage of bulbs of classes 4, 5, and 6, indicating that this practice is important to obtain of bulbs with higher commercial value.

\section{ACKNOWLEDGEMENTS}

The authors thank the Brazilian National Council for Scientific and Technological Development $(\mathrm{CNPq})$ for the financial support to this research project; and the Ministry of Science and Technology, Higher and Technical Vocational Education (MCTESTP) of the Govern of Mozambique for granting a scholarship to the first author.

\section{REFERENCES}

ALVARES, C. A. et al. Köppen's climate classification map for Brazil. Meteorologische Zeitschrift, 22: 711-728, 2013.

FERREIRA, D. F. SISVAR: Um programa para análises e ensino de estatística. Revista Symposium, 6: 36-41, 2011.

FILGUEIRA, F. A. R. Novo Manual de Olericultura: Agrotecnologia moderna na produção e comercialização de hortícola. 3. ed. Viçosa, MG: UFV, 2013. $421 \mathrm{p}$.

FIRISSA, O.; SEYOUM, T.; ABEGAZ, F. Effect of drip lateral spacing and mulching on yield, irrigation water use efficiency and net return of onion (Allium cepa L.) at Ambo, Western Shoa, Ethiopia. Journal of Horticulture and Forestry, 11: 62-69, 2019.

HENRIQUES, G. P. A. et al. Resposta do alho nobre vernalizado à adubação nitrogenada nas condições de cultivo do semiárido tropical. Científica, 47: 62-69, 2019.

HOLANDA, J. S. et al. Indicações para adubação de culturas em solos do Rio Grande do Norte. Parnamirim, RN: EMPARN, 2017. 62 p. (Documentos, 46)

HONORATO, A. R. F. et al. Avaliação de cultivares de alho na região de Mossoró. Revista Caatinga, 26, 80-88, 2013.

KABIR, M. A. et al. Effect of mulching and tillage on yield and keeping quality of garlic (Allium sativum L.), Bangladesh Journal of Agricultural Research, 38:115-125, 2013.
KUMAR, S. D.; LAL, B. R. Effect of Mulching On Crop Production under Rainfed Condition: A Review. International Journal of Research in Chemistry and Environment, 2: 8-20, 2012.

LIMA, M. F. P. et al. Garlic quality as a function of seed clove health and size and spacing between plants. Revista Caatinga, 32: 966-975, 2019.

LOPES, W. A. R. et al. Produção de alho submetido a períodos de vernalização e épocas de plantio em região de clima semiárido. Horticultura Brasileira, 34: 249-256, 2016.

LUCENA, R. R. M. et al. Productive performance of vernalizated semi-noble garlic cultivars in western Rio Grande do Norte state, Brazil. Revista Caatinga, 29: 327-337, 2016.

MORAVČEVIĆ, D. et al. The effect of soil mulching on the quality of the bulb and the yield of different autumn garlic genotypes. IN: INTERNATIONAL SCIENTIFIC AGRICULTURAL SYMPOSIUM (AGROSYM), $\mathrm{n}^{\circ}$ 5, 2014, Jahorina. Proceedings...East Sarajevo: Faculty of Agriculture, 2014, p. $403-408$.

RÊGO, L. G. S. et al. Pedogênese e Classificação de Solos da Fazenda Experimental "Rafael Fernandes" no município de Mossoró, RN. Revista Caatinga, 29: 1036-1042, 2016.

RESENDE, F. V.; DUSI, A. N.; MELO, W. F. Recomendações básicas para a produção de alho em pequenas propriedades. Brasília, DF: Embrapa/ CNPH, 2004. 12p. (Comunicado Técnico, 22).

RESENDE, J. T. V. et al. Caracterização morfológica, produtividade e rendimento comercial de cultivares de alho. Horticultura Brasileira, 31: 157-162, 2013

SEIFU, W. et al. Evaluation of Different Mulching Practices on Garlic (Allium sativum L.) Growth Parameters under Irrigated Condition in Fiche, North Shoa Ethiopia. Journal of Biology, Agriculture and Healthcare, 7: 25-31, 2017.

SOARES, A. M. et al. Avaliação de cultivares de alho no município de Governador Dix-sept RosadoRN, Brasil. Revista Agro@mbiente On-line, 9: 423 $-430,2015$.

SILVA, O. M. P. Crescimento, acúmulo de macronutrientes e adubação fosfatada de alho nobre em região de altitude no semiárido. 2019. 110 f. Tese (Doutorado em Fitotecnia; Área de concentração em Práticas Culturais) - Universidade Federal Rural do Semi-Árido, Mossoró, 2019. 